DOI: 10.17707/AgricultForest.63.2.15

\author{
Witness MOJEREMANE, Thembinkosi MATHOWA, Demel TEKETAY, \\ Tebogo STIMELA, Ishmael KOPONG, Melusi RAMPART ${ }^{1}$
}

\title{
PRESOWING SEED TREATMENT METHODS TO OVERCOME DORMANCY IN SEEDS OF VACHELLIA REHMANNIANA SCHINZ
}

\begin{abstract}
SUMMARY
A germination experiment of Vachellia rehmanniana seeds was conducted in the laboratory of the Department of Crop Science and Production, Botswana University of Agriculture and Natural Resources from November to December 2016. Mature Vachellia rehmanniana seeds were collected from healthy erect trees at Butale Village, Botswana to investigate the effect of different pre-sowing treatment methods on seed germination. The experiment was laid out in a completely randomized design (CRD) with five treatments (control, mechanical scarification, boiling water, hot water and concentrated sulphuric acid (98.8\%)). Boiling water had three different levels of time exposure (1, 3 and $5 \mathrm{~min}$ ) whereas, concentrated sulphuric acid had four different levels of time exposure (15, 30, 45 and $60 \mathrm{~min})$. The results revealed that seed germination percentage, germination mean time and germination index were significantly $(P<0.01)$ affected by pre-treatment methods. The highest significant cumulative germination percentages were recorded in seeds subjected to boiling water for 3 and $5 \mathrm{~min}$, sulphuric acid for 45 and $60 \mathrm{~min}$, and mechanical scarification. Based on the findings mechanical scarification and boiling water techniques are recommended for use in nurseries and by farmers because sulphuric acid is expensive and need to be handled by trained individuals. It is recommended that future research should target increasing the exposure time over five and 60 minutes for boiling water and sulphuric acid treatments, respectively for this species to increase the cumulative germination percentage.
\end{abstract}

Keywords: Vachellia rehmanniana, pre-treatment, seed dormancy, germination percentage.

\section{INTRODUCTION}

The Vachellia, formerly known as Acacia (Kyalangalilwa et al., 2013) is a genus of shrubs and trees that belong to the subfamily Mimosoideae of the family Fabaceae (Palgreaves, 1983). They are widely distributed in arid and semi-arid

\footnotetext{
${ }^{1}$ Witness Mojeremane (corresponding author: wmojerema@bca.bw), Thembinkosi Mathowa, Demel Teketay, Tebogo Stimela, Ishmael Kopong, Melusi Rampart Botswana University of Agriculture and Natural Resources, Department of Crop Science and Production, Private Bag 0027, Gaborone, BOTSWANA.

Notes: The authors declare that they have no conflicts of interest. Authorship Form signed online.
} 
regions where they evolved to withstand harsh climatic and environmental conditions (Timberlake, 1980). The genus Vachellia is one of the most important tree components of the flora of southern Africa (Timberlake, 1980). Vachellia rehmanniana Schinz is very important source of construction wood, firewood (Timberlake, 1980; Hanaoka et al., 2014; Missanjo et al., 2014) and non-wood products (Kassa et al., 2010), such as medicines (Timberlake, 1980; Ali et al., 2012; Missanjo et al., 2014), edible gum and fodder (Hanaoka et al., 2014; Missanjo et al., 2014). In addition, some are nitrogen fixers (Missanjo et al., 2014) and have been used in agroforestry systems (Azad et al., 2011) and soil conservation projects.

Vachellia rehmanniana Schinz, commonly known as silky thorn (Timberlake, 1980; Palgrave, 1983), is a small thorny tree or shrub that grows to 5 m high (Timberlake, 1980), occasionally reaching $10 \mathrm{~m}$ (Timberlake, 1980; Palgrave, 1983). It is deciduous with a flat spreading crown (Palmer and Pitman, 1972; Timberlake, 1980). Leaves are yellow-green, neat slender, composed of 15-40 pairs of slender pinnae, each with many small leaflets (Palmer and Pitman, 1972; Palgrave, 1983). Flowers are in round greenish-white, fragrant balls grouped at the ends of young branches (Palmer and Pitman, 1972; Timberlake, 1980; Palgrave, 1983) appearing before or at the same time with leaves between October and December (Timberlake, 1980). Fruits are straight, dehiscent, aligned and twisted hairless flat pods (Timberlake, 1980; Palgrave, 1983), greyish to olivine in colour (Palgrave, 1983). The species occurs in southern Zambia, Zimbabwe, north eastern Botswana and South Africa, particularly in the Limpopo province (Timberlake, 1980). It grows in wooded grasslands, along river banks and on termite mounds (Timberlake 1980; Palgrave, 1983). It is a drought tolerant multipurpose tree species which provides firewood, construction wood, many non-timber products that include fodder and several ecosystem services. The leaves, young shoots, flowers and pods are eaten by both livestock and wildlife (Tsumele et al., 2007).

The most common and cheap method of raising a large number of plant seedlings is through seeds (Kim et al., 2008). Seeds of many leguminous tree species have hard seed coat impervious to water (Teketay, 1996, 1998; Walters et al., 2004), which exerts a physical exogenous dormancy (Falemara et al., 2014). The hard seed coats hinder germination and limit their propagation (Karthika et al., 2016) as well as their use in afforestation programmes (Botsheleng et al., 2014). Seed germination is an important stage in the life cycle of plant species (Evren and Kucukoduk, 2012) because it determines their survival (Yang et al., 2008). The hard seed coat of many forest species have evolved to withstand unfavourable conditions, such as intense heat from sunlight, dispersing animals, severe drought and physical damage (Tadros et al., 2011). Seed dormancy is an adaptation strategy that ensures seeds germinate only when environmental conditions are suitable for the survival of germinates (Falemara et al., 2014).

Vachellia species are characterized by a hard, seed coat which hinders uptake of water and air by the seed (Teketay, 2005; Aref et al., 2011) to trigger 
germination. For germination to take place, it requires the seed coat to rupture and allow the absorption of water by the seed. Seeds with a hard seed coat require some pre-treatments before sowing to break dormancy and obtain rapid and synchronous germination. Seed dormancy is referred to as a temporary failure of a mature viable seed to germinate when subjected to favourable germination conditions (Ibiang et al., 2012). Numerous techniques have been used to break dormancy in many species with hard coats including species of Vachellia (Teketay, 1998, 2005; Botsheleng et al., 2014; Rasebeka et al., 2014). Different pre-sowing techniques, such as stratification, mechanical, acid and hot water scarification as well as tap water have been widely used (Teketay, 1996, 1998, 2005; Aref et al., 2011; Tadros et al., 2011; Missanjo et al., 2014; Rasebeka et al., 2014; Fredrick et al., 2016) because they can improve germination within a relatively short period of time (Tadros et al., 2011). As with the other leguminous species, seeds of $V$. rehmanniana have hard seed coats, which require pre-sowing treatment to overcome dormancy. However, there is complete lack of information about the pre-sowing methods for overcoming the seed coat-imposed dormancy in $V$. rehmanniana. The objective of this study was, therefore, to investigate the effects of different pre-sowing treatment methods on the germination of seeds of $V$. rehmanniana.

\section{MATERIALS AND METHODS}

\section{Experimental site}

The experiment was carried out in the laboratory at the Botswana University of Agriculture and Natural Resources (BUAN) from November to

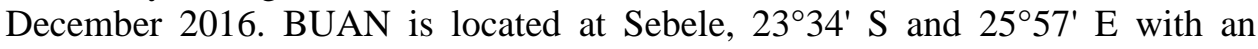
altitude of $994 \mathrm{~m}$ above sea level, $10 \mathrm{~km}$ from the centre of Gaborone City, the Capital of Botswana along the A1 North-South highway.

\section{Seed collection and processing}

The pods of $V$. rehmanniana were collected directly from different healthy, erect and mature mother trees at Butale Village (North East District), eastern Botswana, in September 2016. Subsequently, the pods were placed in a paper bags and transported to the laboratory in BUAN where the seeds were extracted and mixed together. In the laboratory, seeds were screened to remove those showing some signs of damage, and about $4 \%$ of the seeds showed some signs of insect damage. The seeds were kept in a tightly sealed bottle and stored in a cool place awaiting commencement of the study. Prior to the experiment, seeds were immersed in distilled water, and only those that sank and settled at the bottom were used for the experiment. The seeds that floated, which represent unfilled and dead seeds, were discarded.

\section{Seed characteristics}

To assess the seed characteristics of $V$. rehmanniana, the three dimensions of the seeds, namely length, width and breadth of seeds were measured using an electronic digital caliper $(0-150 \mathrm{~mm})$, and their thousand seed weight were determined by weighing the seeds using an electronic analytical balance (Model: 
PW 124). Five replications of 10 seeds and ten replications of 100 seeds were used to determine the mean dimensions and thousand seed weights of the seeds, respectively. The thousand seed weight of the seeds was, then, computed from the mean seed weight of the 100 seeds.

\section{Experimental design and germination experiment}

The experiment was laid out in a completely randomized design (CRD) with five treatments, i.e. mechanical scarification, boiling water, hot water, concentrated sulphuric acid (98.8\%) and control. The boiling water treatment had three different levels of exposure time (1, 3 and 5 minutes) whereas the concentrated sulphuric acid treatment had four different levels of exposure time (15, 30, 45 and 60 minutes). Each treatment had 100 seeds replicated four times with 25 seeds in each replication. The seeds were germinated in petri dishes lined with cotton wool, which was kept continuously moist with distilled water.

\section{Pre-sowing seed treatment procedures}

In the mechanical scarification treatment, the seeds were scarified by carefully nicking the seed coat at the distal end by hand with a nail cutter. In the boiling water treatment, first seeds were enclosed in coffee filter papers and clipped tightly to avoiding any of them falling out and, then, immersed in boiling water for 1,3 and 5 minutes. They were then removed from the boiling water and left to cool down on a table. Before the hot water treatment, water was boiled to up to approximately $100^{\circ} \mathrm{C}$. Then, the simmering hot water (about $98.5^{\circ} \mathrm{C}$ ) was poured in a $100 \mathrm{ml}$ heat resistant glass beaker containing the seeds, which was left to gradually cool for 24 hours at room temperature. For the sulphuric acid treatment, the method described by Botsheleng et al. (2014) was followed. Four hundred seeds were counted from the seed lot and then divided into batches of 100 seeds. The seeds were, then, put into four $100 \mathrm{ml}$ heat resistant non-corrosive glass beakers and concentrated sulphuric acid (98.8\%) was added slowly on the side of the beakers to a level where all seeds were covered (about $50 \mathrm{ml}$ ). Seeds in the four beakers were left in the sulphuric acid for different time periods (15, 30,45 and 60 minutes), and they were stirred regularly to ensure equal exposure of the seeds to the acid. After each soaking period, the sulphuric acid was drained off, and the seeds were repeatedly rinsed in running tap water until they were considered safe to handle. The control consisted of seeds that did not receive any treatment.

\section{Germination assessment}

The counting of germinated seeds was done daily, and a seed was considered germinated when the radicle reached about $2 \mathrm{~mm}$. The experiment was terminated after 21 days.

\section{Data analyses}

Data collected on the germination of seeds were used to calculate germination percentage, germination mean time and germination index for each treatment using the equations below. 
Germination percentage (GP), which represents the number of germinated seeds as a percentage of the total number of tested seeds, was computed using the following formula:

GP $(\%)=($ germinated seeds/total tested seeds $) \times 100$

Germination mean time (GMT) and germination index (GI) were calculated as follows (Botsheleng et al., 2014):

GMT (days) $=\Sigma \mathrm{T}_{\mathrm{i}} \mathrm{N}_{\mathrm{i}} / \mathrm{S}$

where, $\mathrm{T}_{\mathrm{i}}=$ number of days from the beginning of the experiment, $\mathrm{N}_{\mathrm{i}}=$ number of seeds germinated per day and $\mathrm{S}=$ total number of seeds germinated.

$\mathrm{GI}=\left(\mathrm{G}_{1} / 1\right)+\left(\mathrm{G}_{2} / 2\right)+\ldots+\left(\mathrm{G}_{\mathrm{x}} / \mathrm{x}\right)$

where, $\mathrm{G}=$ germination day $1,2 \ldots$, and $\mathrm{x}=$ the corresponding day of germination.

To test if there were significant differences among treatment means, the data were further subjected to one-way analyses of variance (ANOVA) using Analytical Software (2003), following arcsine transformation of all percentage data. Significant differences of means were tested using Tukey's Studentized Range (HSD) at the significance level of $\mathrm{P} \leq 0.05$.

\section{RESULTS AND DISCUSSION}

Table 1. Effect of seed pre-treatment on mean germination parameters of V. rehmanniana.

\begin{tabular}{|c|c|c|c|}
\hline Treatments & $\begin{array}{l}\text { Cumulative mean } \\
\text { germination }(\%)\end{array}$ & GMT (days) & GI \\
\hline Control & $3.00^{\mathrm{d}}$ & $1.50^{c}$ & $0.01^{\mathrm{c}}$ \\
\hline Mechanical scarification & $69.00^{\mathrm{ab}}$ & $4.53^{\mathrm{abc}}$ & $0.82^{\mathrm{ab}}$ \\
\hline \multicolumn{4}{|l|}{ Boiling water } \\
\hline $1 \mathrm{~min}$ & $24.00^{c}$ & $6.88^{\mathrm{a}}$ & $0.22^{c}$ \\
\hline $3 \min$ & $73.00^{\mathrm{a}}$ & $4.56^{\mathrm{abc}}$ & $0.87^{\mathrm{a}}$ \\
\hline $5 \mathrm{~min}$ & $68.00^{\mathrm{ab}}$ & $4.54^{\mathrm{abc}}$ & $0.81^{\mathrm{ab}}$ \\
\hline Hot water-24 hrs & $4.00^{\mathrm{d}}$ & $1.00^{\mathrm{C}}$ & $0.03^{\mathrm{c}}$ \\
\hline \multicolumn{4}{|l|}{ Sulphuric acid (98\%) } \\
\hline $15 \mathrm{~min}$ & $4.00^{\mathrm{d}}$ & $1.63^{\mathrm{bc}}$ & $0.03^{c}$ \\
\hline $30 \mathrm{~min}$ & $24.00^{\mathrm{C}}$ & $6.42^{\mathrm{a}}$ & $0.21^{\mathrm{c}}$ \\
\hline $45 \mathrm{~min}$ & $52.00^{\mathrm{b}}$ & $6.27^{\mathrm{ab}}$ & $0.62^{\mathrm{b}}$ \\
\hline $60 \mathrm{~min}$ & $71.00^{\mathrm{ab}}$ & $4.32^{\mathrm{abc}}$ & $0.85^{\mathrm{ab}}$ \\
\hline Significance & $* *$ & $* *$ & $* *$ \\
\hline HSD & 19.99 & 4.76 & 0.23 \\
\hline CV (\%) & 21.13 & 47.33 & 21.28 \\
\hline
\end{tabular}

** Highly significant at $\mathrm{P}<0.01$. Means separated using Tukey's Studentized Range (HSD) Test at $\mathrm{P} \leq 0.05$; means within columns followed by the same letters are not significantly different. GMT = germination mean time and GRI = germination index. 
The mean length, width and breadth of seeds were $7.1 \pm 0.08,6.3 \pm 0.08$ and $3 \pm 0.06 \mathrm{~mm}$, respectively, with minimum and maximum ranges of 6.7-7.5, 5.8 - 6.6 and $2.7-3.2 \mathrm{~mm}$, respectively. The mean thousand seed weight of the seeds was $93.5 \pm 0.95 \mathrm{~g}$, ranging between 88.3 and $97 \mathrm{~g}$.

The results indicated that seed germination percentage, germination mean time and germination index were significantly $\left(\mathrm{F}_{(9,30)}=51.4, \mathrm{P}<0.01\right)$ affected by pre-sowing treatment methods (Table 1). Overall, the highest cumulative germination percentages at termination of the experiment were recorded in seeds subjected to boiling water for 3 minutes (73\%), followed by seeds subjected to sulphuric acid for 60 minutes (71\%), nicking (69\%) and seeds subjected to boiling water for 5 minutes (68\%) (Figure 1). No statistical differences in germination percentages were observed among the above treatments. Results also show no significant differences $(\mathrm{P}>0.05)$ in cumulative germination percentages between seeds soaked in boiling water (1 minute) and those soaked in sulphuric acid (30 minutes). The lowest cumulative germination percentages were recorded in the control (3\%) followed by hot water (24 hours) and sulphuric acid (15 minutes).

Different pre-treatment methods have been used to break dormancy to stimulate prompt and uniform germination of seeds (Teketay, 2005; Sahoo et al., 2007; Aref et al., 2011; Botsheleng et al., 2014; Rasebeka et al., 2014; Frederick et al., 2016). No single pre-treatment method has been reported to be effective across plant species (Amusa, 2011). Mechanical scarification has been shown to enhance germination in seeds of many species (Teketay, 1996, 1998, 2005; Likoswe et al., 2008; Aref et al., 2011; Olatunji et al., 2013; Missanjo et al., 2014). Present results show that mechanical scarification significantly $(P<0.01)$ improved germination compared with the control. These results demonstrated the effectiveness of mechanical scarification in overcoming physical dormancy, which is imposed by a hard seed coat that prevent the seed from taking up water, the first critical step in germination (Teketay, 2005; Chisha-Kasumu et al., 2007). Chisha-Kasumu et al. (2007) recorded the highest rate of germination in mechanically scarified Pterocarpus angolensis DC. seeds within 5 days of sowing. Mechanical scarification cracks part of the hard seed coat which is a barrier to water uptake and gaseous exchange (Teketay, 2005; Azad et al., 2011) and allow germination to proceed (Olatunji et al., 2013). The results of the present experiment indicate that the seed dormancy found in $V$. rehmanniana is caused by physical rather than embryo dormancy.

Soaking seeds in boiling water (1, 3 and 5 minutes) was effective in improving germination compared with the control. However, seed germination percentages of seeds soaked in boiling water for 3 and 5 minutes were significantly higher $(\mathrm{P}<0.01)$ than those soaked for 1 minute. Results indicated that soaking seeds in boiling water for a few minutes break their physical dormancy and allow their subsequent germination. The effectiveness of boiling water observed in this work could probably be attributed to the softening of the hard seed coat, which allowed entrance of water and air into the seed to induce 
physiological changes (Teketay, 2005; Pahla et al., 2014, Rasebeka et al., 2014) that subsequently triggered germination (Rasebeka et al., 2014). Present results are consistent with McDonald and Omoruyi (2003) who reported the highest seed germination (70\%) in Dialium guineense Wild. seeds soaked in boiling water $\left(100{ }^{\circ} \mathrm{C}\right)$ for 5 minutes. The fact that soaking seeds in boiling water for 1 minute was not as effective as the 3 and 5 minutes soaking durations could be attributed to the degree of the seed coat thickness. These results suggest that the seed coat thickness of V. rehmanniana requires soaking in boiling water for longer duration.
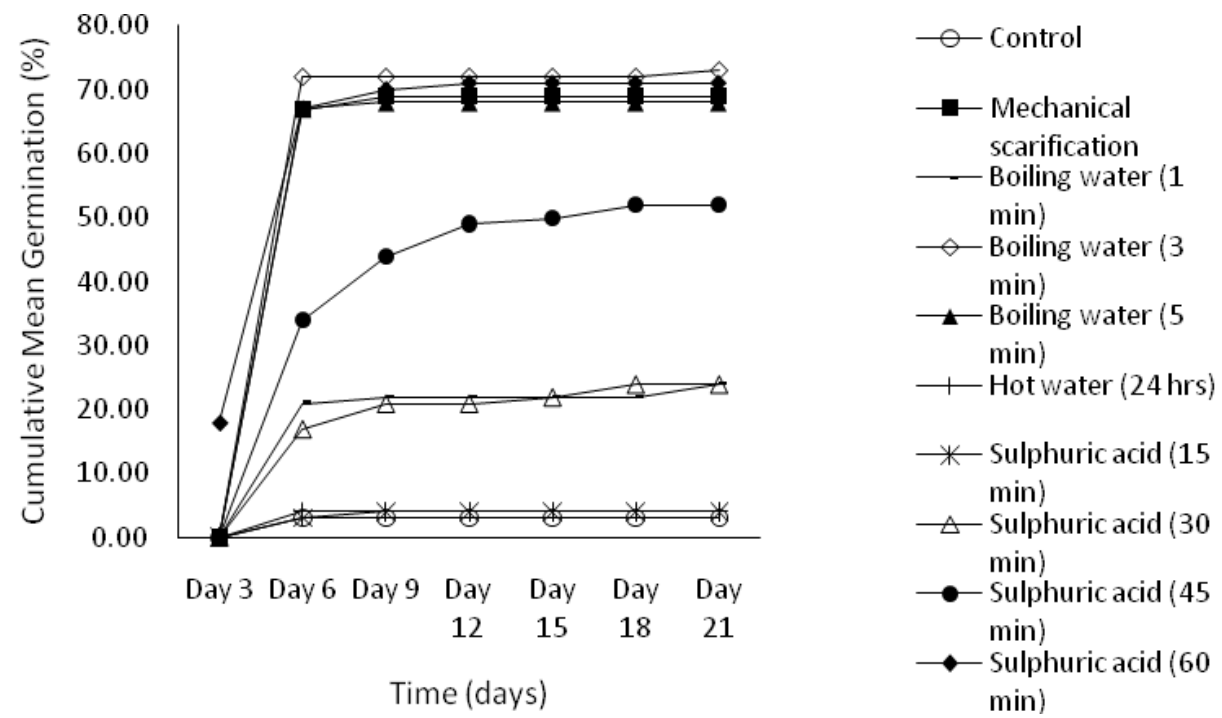

Figure 1. Cumulative mean germination (\%) over time as influenced by presowing seed treatments.

Hot water treatment is frequently used to overcome dormancy in seeds with a hard coat. When using this method, seeds are soaked at $40-100{ }^{\circ} \mathrm{C}$ for a period of time, depending on the species and seed coat thickness or until the boiling water cools to ambient (Tadros et al., 2011). There was no significant difference in germination percentages between seeds soaked in hot water for 24 hrs and the control. These results are in agreement with studies conducted elsewhere using seeds of different tree species (Teketay, 1996, 1998; Botsheleng et al., 2014; Fredrick et al., 2016). The effectiveness of hot water in breaking seed dormancy varies from species to species (Tigabu and Oden, 2001; Teketay, 2005). For example, Albrecht (1993) reported that soaking seeds for 24 hrs in water boiled to $100{ }^{\circ} \mathrm{C}$ was effective in breaking the seed coat dormancy of Adansonia digitata L., Calliandra calothyrsus Meissner and Sesbania sesban (L.) Merr. Tadros et al. (2011) observed that soaking Leucaena leucocephala (Lam.) de Wit seeds in $70{ }^{\circ} \mathrm{C}$ water for 20 minutes was effective in breaking seed 
dormancy and enhancing seed germination. The results indicate that V. rehmanniana has a very tough seed coat, which is in agreement with Aref (2000) who reported hard coats in other Vachellia species. The hard seed coat is one of the several strategies that the Vachellia species use to survive in the spatially and temporally variable environment (Aref, 2000). It is possible that the hot water in the present study cooled off before the hard seed coat was soft enough to allow entry of water and air.

Sulphuric acid (30, 45, and 60 minutes) improved seed germination compared with the control. This is consistent with results from other studies that reported prompt and uniform germination in hard water impermeable seed coated seeds soaked in sulphuric acid (Muhammad and Amusa, 2003; McDonald and Omoruyi, 2003; Keshtkar et al., 2008; Likoswe et al., 2008; Aref et al., 2011). Seed germination in the present study increased with soaking period in sulphuric acid. Muhammad and Amusa (2003) recorded the highest germination in Tamarindus indica L. seeds soaked in sulphuric acid (50\%) for 60 minute. Sulphuric acid disrupts the seed coat and expose the lumens of the macrosclereids cells, permitting imbibition of water, which triggers seed germination (Aliero, 2004; Amusa, 2011). The germination of seeds soaked in sulphuric acid for 15 minutes did not significantly differ from the control indicating that $V$. rehmanniana seeds are characterized by hard seed coat, which requires longer soaking periods in sulphuric acid to reduce its thickness.

The lowest mean germination durations (days) were recorded in seeds soaked in hot water for 24 hrs (1) followed by control (1.5) and seeds soaked in sulphuric acid for $15 \mathrm{~min}$ (1.63). These together with high coefficient of variation (47.33) revealed indicates that the three treatments had difficulties breaking the hard seed coat exhibited by $V$. rehmanniana recording no germination in almost all the replications. However, the rest of the treatments were evenly spread between 4.32 and 6.88 days with no statically differences. The few seeds which germinated as evidenced by the highest germination percentage (73\%) after 21 days across the treatments germinated within a reasonable period. As would be expected, seeds subjected to boiling water for 3 and 5 minutes, sulphuric acid for 45 and 60 minutes and mechanical scarification had the highest germination index ranging from 0.6 to 0.9 . As a ratio, this shows that treatments were superior to others.

\section{CONCLUSION}

Mechanical scarification, boiling water (3 and 5 minutes) and concentrated sulphuric acid (45 and 60 minutes) proved to be effective in improving seed germination in V. rehmanniana in the present study. However, mechanical scarification and boiling water methods are recommended for use in nurseries and by farmers because sulphuric acid is expensive and needs to be handled by trained individuals. Authors also recommend increased exposure time over 5 and 60 minutes for boiling water and sulphuric acid respectively. 


\section{ACKNOWLEDGEMENTS}

The authors would like to thank the Botswana University of Agriculture and Natural Resources for providing facilities for the research activities. We are grateful to Constance Mojeremane for her involvement in the seed collection.

\section{REFERENCES}

Albrecht J. 1993. Tree seed handbook of Kenya. GTZ forestry seed centre, Muguga. Kenya Forest Research Institute, GTZ/KEFRI p 264

Ali A, Akhtar N, Khan BA, Khan MS, Rasul A, Khalid N, Waseem K, Mahmood T and Ali L. 2012. Acacia nilotica: a plant of multipurpose medicinal uses. Journal of Medicinal Plants Research, 6(9):1492-6

Aliero BL. 2004. Effects of sulphuric acid, mechanical scarification and wet heat treatments on germination of seeds of African locust bean tree, Parkia biglobosa. African Journal of Biotechnology, 3(3):179-181.

Amusa TO. 2011. Effects of three pre-treatment techniques on dormancy and germination of seeds of Afzelia africana (Sm. Ex pers). Journal of Horticulture and forestry, 3(4):96-103.

Analytical Software. 2003. STATISTIX 8 for Windows. Tallahassee, Florida, US.

Aref IM, Atta HAE, Shahrani TA and Mohamed AI. 2011. Effects of seed pretreatment and seed source on germination of five Acacia spp. African Journal of Biotechnology, 10(71):15901-15910.

Aref IM. 2000. Morphological characteristics of seeds and seedling growth of some native acacia trees in Saudi Arabia. Journal of King Saud University, Agricultural Sciences, 12(2):31-95.

Azad S, Manik MR, Hasan S and Matin A. 2011. Effect of different pre-sowing treatments on seed germination percentage and growth performance of Acacia auriculiformis. Journal of Forestry Research, 22: 183. doi: 10.1007/s11676011-0147-y.

Botsheleng B, Mathowa T and Mojeremane W. 2014. Effects of pre-treatments methods on the germination of Pod mahogany (Afzelia quanzensis) and mukusi (Baikiaea plurijuga) seeds. International Journal of Innovative Research in Science Engineering and Technology, 3(1):8108-8113.

Chisha-Kasumu, E, Woodward, S and Price A. 2007. Comparison of the effects of mechanical scarification and gibberellic acid treatments on seed germination in Pterocarpus angolensis. Southern Hemisphere Forestry Journal, 69(1):6370 .

Evren Y and Kucukoduk M. 2012. Dormancy breaking and germination requirements for seeds of Sphaerophysa kotschyana boiss. Journal of Global Biosciences, 1: 20-27.

Falemara BC, Chomini MS, Thlama DM and Udenkwere M. 2014. Pre-germination and dormancy response of Adansonia digitata L seeds to pre-treatment techniques and growth media. European Journal of Agriculture and Forestry Research, 2(1):13-23.

Fredrick C, Muthuri C, Ngamau K and Sinclair F. 2016. Provenance and pretreatment effect on seed germination of six provenances of Faidherbia albida (Delile) A. Chev. Agroforestry Systems, doi:10.1007/s10457-016-9974-3. 
Hanaoka S, Nakawa N, Okubo N, Omondi SF, Kariuki J. 2014. Seed pre-treatment methods for improving germination of Acacia tortilis. African Journal of Biotechnology 13(50):4557-4561.

Holmes RJ, McDonald JNAW and Juritz J. 1987. Effects of clearing treatment on seed bank of the Alinene invasive shrubs Acacia saligna and Acacia cyclops in the southern and south western Cape, South Africa. Journal of Applied Ecology, 24: 1045-1051.

Ibiang YB, Ita EE, Ekanem BE and Edu, NE. 2012. Effect of different pre-treatment protocols on seed germination of Tetrapleura tetraptera (Schum and Thonn). Journal of Environmental Science, Toxicology and Food Technology, 2(3):2529.

Karthika C, Mohamed RK and Manivannan S. 2016. Effect of different pre-treatment on in vitro seed germination and seedling development of Senna Alata Linn. International Journal of Pharmaceutical Science and Research, 7(5):21572162.

Kassa A, Alia R, Tadesse W, Pando V and Bravo F. 2010. Seed germination and viability in two African Acacia species growing under different water stress levels. African Journal of Plant Science, 4(9):353-359.

Keshtkar AR, Keshtkar HR, Razavi SM and Dalfardi S. 2008. Methods to break seed dormancy of Astragalus cyclophyllon. African Journal of Biotechnology 7(21):3874-3877.

Kim RE, Jung HH and Kim KS. 2008. Seed germination of Carex neurocarpa maxim is promoted by fluctuating temperatures and seed scarification. Horticulture Environment and Biotechnology, 49(3):162-167.

Kyalangalilwa B, Boatwright JS, Daru BH, Maurin O, and van der Bank M. 2013. Phylogenetic position and revised classification of Acacia s.l. (Fabaceae: Mimosoideae) in Africa, including new combinations in Vachellia and Senegalia. Botanical Journal of the Linnean Society, 172: 500-523.

Likoswe MG, Njoloma JP, Mwase WF and Chilima, CZ. 2008. Effect of seed collection times and pre-treatment methods on germination of Terminalia sericea Burch. Ex DC. African Journal of Biotechnology, 7(16): 2840-2846.

MacDonald I and Omoruyi, O. 2003. Effect of seed pre-treatment on germination of two surface types of Dialium guineense. Seed Technology, 25(1):41-44.

Missanjo E, Chioza A and Kulapani C. 2014. Effects of different pre-treatments to the seed on seedling emergence and growth of Acacia polyacantha. International Journal of Forestry Research, http://dx.doi.org/10.1155/2014/583069.

Muhammad S and Amusa NA. 2003. Effects of sulphuric acid and hot water treatments on seed germination of tamarind (Tamarindus indica L). African Journal of Biotechnology, 2(9):276-279.

Olatunji DJ, Maku O and Odumefun OP. 2013. The effect of pre-treatments on the germination and early seedlings growth of Acacia auriculiformis Cunn. Ex.

Benth. African Journal of Plant Science, 7(8):325-330.

Palgrave KC. 1983. Trees of Southern Africa. Struik, Cape Town, pp. 248. 
Pahla I, Muziri T, Chinyise T, Muzemu, S and Chitamba J. 2014. Effects of soil type and different pre-sowing treatments on seedling emergence and vigour of Acacia sieberana. International Journal of Plant Research, 4(2):51-55

Palmer E and Pitman N. 1972. Trees of Southern Africa. A.A.Balkema, Cape Town, pp.783.

Rasebeka L, Mathowa T and Mojeremane W. 2014. Effect of seed pre-sowing treatment on germination of three Acacia species indigenous to Botswana. International Journal of Plant and Soil Science, 3(1):62-70.

Tadros MJ, Samarah NH and Alqudah AM. 2011. Effect of different pre-sowing seed treatments on the germination of Leucaena leucocephala (Lam.) and Acacia farnesiana (L.). New forests, 42(3):397-407.

Teketay, D. 1996. Germination Ecology of twelve indigenous and eight exotic multipurpose leguminous species from Ethiopia. Forest Ecology and Management 80: 209-223.

Teketay D. 1998. Germination of Acacia origena, A. pilespina and Pterolobium stellatum in response to different pre-sowing seed treatments, temperature and light. Journal of Arid Environments, 38(4): 551-560.

Teketay, D. 2005. Seed and regeneration ecology in dry Afromontane forests of Ethiopia: I. Seed production - population structures. Tropical Ecology 46: 2944.

Timberlake J. 1980. Botswana acacias. Ministry of Agriculture. Gaborone, pp. 81.

Sahoo UK, Upadhyaya K and Lalrempuia H. 2007. Effect of pre-treatment and temperature on the germination behaviour of seeds of Parkia roxburghii G Don. Forests, Trees and Livelihoods, 17(4):345-350.

Tsumele J, Mlambo D and Sebata A. 2007. Response of three Acacia species to simulated herbivory in a semi-arid southern African savanna. African Journal of Ecology, 45(3):324-326.

Walters M, Midgley JJ and Somers MJ. 2004. Effects of fire and fire intensity on the germination and establishment of Acacia karoo, Acacia nilotica, Acacia luederitzii and Dichrostachys cinerea in the field. BMC. Ecology 4:3; doi: 10.1186/1472-6785-4-3.

Yang QH, Wei X, Zeng XL, Ye WH, Yin XJ, Zhang-Ming W and Jiang YS. 2008. Seed biology and germination ecophysiology of Camellia nitidissima. Forest Ecology and Management, 255(1):113-118. 